\title{
REGULASI DAN MEKANISME IMPOR LIMBAH NON-BAHAN BERBAHAYA DAN BERACUN DALAM RANGKA PERLINDUNGAN DAN PENGELOLAAN LINGKUNGAN HIDUP
}

\author{
Liza Evita \\ Ridarson Galingging \\ Fakultas Hukum Universitas YARSI \\ Email : liza.evita@yarsi.ac.id
}

\begin{abstract}
Abstrak
Limbah Non B3 sebagai Bahan Baku Industri dapat diimpor apabila: tidak berasal dari kegiatan landfill, bukan sampah dan tidak tercampur sampah, tidak terkontaminasi B3 dan Limbah B3, dan homogen. Penelitian hukum normatif. Bagaimana Regulasi dan Mekanisme Impor Limbah Non-Bahan Berbahaya Dan Beracun Dalam Rangka Perlindungan Dan Pengelolaan Lingkungan Hidup. Peraturan Menteri Perdagangan No 84 Tahun 2019, limbah non B3 dapat diimpor untuk bahan baku industri. Untuk mendapatkan Persetujuan Impor (PI), perusahaan harus mengajukan permohonan secara elektronik kepada Direktur Jenderal Perdagangan.
\end{abstract}

Kata kunci : Impor Limbah, Non B3

\section{Abstract}

Non-hazardous waste as industrial raw material can be imported if: it does not come from landfill activities, is not garbage and is not mixed with waste, is not contaminated with B3 and B3 waste, and is homogeneous. Normative legal research. How are the Regulations and Mechanisms for Importing NonHazardous and Toxic Wastes in the Context of Environmental Protection and Management. Regulation of the Minister of Trade No. 84 of 2019, non-B3 waste can be imported for industrial raw materials. To get an Import Approval (PI), a company must submit an application electronically to the Director General of Trade.

Key words: Imported Waste, Non B3

\section{PENDAHULUAN}

Akhir-akhir ini, Indonesia kerap menerima limbah impor dari Amerika Serikat (AS), Australia, Prancis, Jerman dan Hongkong, karena adanya muatan sampah Bahan Berbahaya dan Beracun (B3), akhirnya, sampah tersebut dipulangkan ke negara asal. Dalam Peraturan Menteri Perdagangan Nomor 31 Tahun 2016 tentang Ketentuan Impor Limbah Non Bahan Beracun Berbahaya, kegiatan impor limbah yang dapat dilakukan adalah kegiatan impor limbah non-B3. Dalam aturan itu disebutkan bahwa limbah non-B3 
yang dapat diimpor hanya berupa sisa, reja (sisa buangan) dan scrap. Lebih lanjut, limbah non-B3 yang dimaksud juga tidak terkontaminasi limbah B3 atau limbah lainnya yang tidak diatur dalam Permendag Nomor 31 Tahun 2016.

Importir juga harus mengantongi persetujuan impor disertai lampiran surveyor agar dapat mengimpor sampah. Namun aturan ini tak selamanya diindahkan seperti kasus yang terjadi di Batam, Kepulauan Riau. Ditjen Bea Cukai Kementerian Keuangan mendapati adanya limbah B3 disusupkan masuk dalam kontainer yang berisi limbah non-B3. Pada saat pemeriksaan ada limbah B3 padahal dokumen persetujuan impor adalah non-B3. kata Kasi Humas Dirjen Bea Cukai Sudiro, Rabu (3/7/2019). Akibat pelanggaran tersebut, Bea Cukai langsung memprosesnya untuk dikembalikan ke negara asal. ${ }^{1}$

Negara, pemerintah, dan seluruh pemangku kepentingan berkewajiban untuk melakukan perlindungan dan pengelolaan lingkungan hidup dalam pelaksanaan pembangunan berkelanjutan agar lingkungan hidup Indonesia dapat tetap menjadi sumber dan penunjang hidup bagi rakyat Indonesia serta makhluk hidup lain. Hal ini sejalan dengan amanat UndangUndang Dasar Negara Republik Indonesia Tahun 1945 menyatakan bahwa lingkungan hidup yang baik dan sehat merupakan hak asasi dan hak konstitusional bagi setiap warga negara Indonesia. Artinya setiap Warga Negara Indonesia berkewajiban untuk melestarikan fungsi lingkungan hidup dan mencegah terjadinya pencemaran dan/atau kerusakan lingkungan hidup.

Undang-Undang Nomor 32 Tahun 2009 tentang Perlindungan dan Pengelolaan Lingkungan Hidup (UUPPLH) telah mengatur Pasal 69 Setiap orang dilarang:

Melakukan perbuatan yang mengakibatkan pencemaran dan/atau perusakan lingkungan hidup; memasukkan B3 yang dilarang menurut peraturan perundang undangan ke dalam wilayah Negara Kesatuan Republik Indonesia; memasukkan limbah yang berasal dari luar wilayah Negara Kesatuan Republik Indonesia 
ke media lingkungan hidup Negara Kesatuan Republik Indonesia; memasukkan limbah B3 ke dalam wilayah Negara Kesatuan Republik Indonesia;

\section{Rumusan Masalah}

Bagaimana Regulasi dan Mekanisme Impor Limbah Non-Bahan Berbahaya Dan Beracun Dalam Rangka Perlindungan Dan Pengelolaan Lingkungan Hidup

\section{Tujuan Penelitian}

Untuk mengkaji Regulasi dan Mekanisme Impor Limbah Non-Bahan Berbahaya Dan Beracun Dalam Rangka Perlindungan Dan Pengelolaan Lingkungan Hidup

\section{Manfaat Penelitian}

1. Teoritis

Hasil penelitian ini diharapkan dapat menambah khasanah keilmuan khususnya bidang hukum lingkungan.

2. Praktis

Hasil penelitian ini diharapkan dapat menjadi pengetahuan bagi masyarakat dan masukan bagi pemerintah daerah dalam penyusunan peraturan daerah yang berhubungan dengan Regulasi dan Mekanisme Impor Limbah Non-Bahan Berbahaya Dan Beracun Dalam Rangka Perlindungan Dan Pengelolaan Lingkungan Hidup,

\section{KAJIAN PUSTAKA}

Sampah adalah sisa kegiatan sehari-hari manusia dan/atau proses alam yang berbentuk padat. Penghasil sampah adalah setiap orang dan/atau akibat proses alam yang menghasilkan timbulan sampah. Pengelolaan sampah diselenggarakan berdasarkan asas tanggung jawab, asas berkelanjutan, asas manfaat, asas keadilan, asas kesadaran, asas kebersamaan, asas keselamatan, asas keamanan, dan asas nilai ekonomi. Pengelolaan sampah bertujuan untuk meningkatkan kesehatan masyarakat dan kualitas lingkungan serta menjadikan sampah sebagai 
sumber daya. ${ }^{2}$

Bahan berbahaya dan beracun yang selanjutnya disingkat

adalah zat, energi, dan/atau komponen lain yang karena sifat, konsentrasi, dan/atau jumlahnya, baik secara langsung maupun tidak langsung, dapat pencemarkan dan/atau merusak lingkungan hidup, dan/atau membahayakan lingkungan hidup, kesehatan, serta kelangsungan hidup manusia dan makhluk hidup lain. Limbah bahan berbahaya dan beracun (Limbah B3) adalah sisa suatu usaha dan/atau kegiatan yang mengandung B3.

Pasal 39 UU No 18 Tahun 2008 tentang Pengelolaan Sampah : Setiap orang yang secara melawan hukum memasukkan dan/atau mengimpor sampah rumah tangga dan/atau sampah sejenis sampah rumah tangga ke dalam wilayah Negara Kesatuan Republik Indonesia diancam dengan pidana penjara paling singkat 3 (tiga) tahun dan paling lama 9 (sembilan) tahun dan denda paling sedikit Rp100.000.000,00 (seratus juta rupiah) dan paling banyak Rp3.000.000.000,00 (tiga miliar rupiah);

\section{METODE PENELITIAN}

\section{Jenis Penelitian}

Penelitian ini difokuskan atau dititikberatkan pada penelitian hukum normatif, yang menganalisis substansi hukum sehingga tidak terlepas dari metode normatif analisis, yang bertolak dari peraturan perundang-undangan yang mempunyai daya otoritas sebagai bahan hukum primer. Pendekatan yang dipergunakan dalam penelitian ini adalah pendekatan perundang-undangan (statute approach) dilihat hukum sebagai suatu sistem yang tertutup yang mempunyai sifat sebagai berikut : . 3

1. Comprehensive, artinya norma hukum yang ada di dalamnya terkait antara satu dengan yang lain secara logis;

2. All-inclusive, bahwa kumpulan norma hukum tersebut cukup mampu menampung permasalahan hukum yang ada sehingga tidak akan ada kekurangan hukum;

${ }^{2}$ Pasal 1, 3 dan 4 Undang-Undang No.18 tahun 2008 tentang Pengelolaan Sampah

3 Johny Ibrahim, Teori dan Metodelogi Penelitian Hukum Normatif (Surabaya, Bayumedia, 2007), hlm. 301 
3. Systematic, bahwa di samping bertautan antara satu dengan yang lain, norma-norma hukum tersebut tersusun secara sistematis

Dalam metode pendekatan perundang-undangan, peneliti perlu memahami hierarki, dan asas-asas dalam peraturan perundang-undangan. Berkaitan dengan pendekatan peraturan perundang-undangan ini, peneliti melakukan pengkajian terhadap segala bentuk peraturan perundang-undangan sesuai dengan hierarkinya yang relevan dengan isu hukum yang sedang dikaji mulai dari UUD Negara Republik Indonesia Tahun 1945, Undang-undang, Peraturan Pemerintah dan seterusnya berdasarkan Undang-Undang RI No. 12 Tahun 2011 tentang Pembentukan Peraturan Perundang-Undangan. ${ }^{4}$ Sebagai penelitian hukum normatif, untuk memecahkan isu-isu hukum dan sekaligus memberikan preskripsi atau resep/formula mengenai bagaimana seharusnya Regulasi dan Mekanisme Partisipasi Masyarakat Dalam Proses Amdal dan Izin Lingkungan

\section{Cara penetapan dan Sampel Penelitian}

Metode pengambilan sampel adalah dengan menggunakan metode purposive sampling, merupakan metode pengambilan sampel dimana peneliti memiliki kriteria atau tujuan tertentu terhadap sampel yang akan diteliti. Kriterianya adalah instansi yang mempunyai kewenangan dalam membuat

4 Berdasarkan Pasal 7 UU No. 12 tahun 2011 tentang Pembentukan Peraturan Perundang-Undangan, jenis dan hierarki Peraturan Perundang-undangan terdiri atas:

a. Undang-Undang Dasar Negara Republik Indonesia Tahun 1945;

b. Ketetapan Majelis Permusyawaratan Rakyat;

c. Undang-Undang/Peraturan Pemerintah Pengganti Undang-Undang;

d. Peraturan Pemerintah;

e. Peraturan Presiden;

f. Peraturan Daerah Provinsi; dan

g. Peraturan Daerah Kabupaten/Kota

Berdasarkan Pasaal 8 UU No 12 tahun 2011,

(1) Jenis Peraturan Perundang-undangan selain sebagaimana dimaksud dalam Pasal 7 ayat (1) mencakup peraturan yang ditetapkan oleh Majelis Permusyawaratan Rakyat, Dewan Perwakilan Rakyat, Dewan Perwakilan Daerah, Mahkamah Agung, Mahkamah Konstitusi, Badan Pemeriksa Keuangan, Komisi Yudisial, Bank Indonesia, Menteri, badan, lembaga, atau komisi yang setingkat yang dibentuk dengan UndangUndang atau Pemerintah atas perintah Undang-Undang, Dewan Perwakilan Rakyat Daerah Provinsi, Gubernur, Dewan Perwakilan Rakyat Daerah Kabupaten/Kota, Bupati/Walikota, Kepala Desa atau yang setingkat.

(2) Peraturan Perundang-undangan sebagaimana dimaksud pada ayat (1) diakui keberadaannya dan mempunyai kekuatan hukum mengikat sepanjang diperintahkan oleh Peraturan Perundang-undangan yang lebih tinggi atau dibentuk berdasarkan kewenangan 
Regulasi dan Mekanisme Partisipasi Masyarakat Dalam Proses Amdal dan Izin Lingkungan

\section{Jenis Bahan Hukum}

Sebagai penelitian hukum normatif, untuk memecahkan isu-isu hukum dan sekaligus memberikan preskripsi atau resep/formula mengenai bagaimana seharusnya Regulasi Dan Mekanisme Impor Limbah Non-Bahan Berbahaya Dan Beracun Dalam Rangka Perlindungan Dan Pengelolaan Lingkungan Hidup. Bahan hukum primer merupakan bahan hukum yang bersifat otoritatif, artinya mempunyai otoritas. Bahan hukum primer yang dibutuhkan dalam penelitian ini meliputi :

a. UUD NRI Tahun 1945 ;

b. Peraturan perundang-undangan yang terkait dengan perlindungan dan pengelolaan lingkungan hidup yang berlaku saat ini atau pernah berlaku sebelumnya

c. Peraturan perundang-undangan yang terkait dengan import non bahan berbahaya dan beracun

Instrumen Pengumpulan Bahan Hukum

Keseluruhan bahan hukum dalam penelitian ini diperoleh melalui studi pustaka (library research), studi dokumentasi, penelusuran bahan hukum melalui internet. Selain bahan hukum yang diperoleh dari penelitian kepustakaan, sebagai penunjang akan dilakukan penelitian lapangan untuk mendapatkan data primer melalui wawancara dengan pihak-pihak terkait.

Analisis Data

Bahan hukum primer dan bahan hukum sekunder yang telah terkumpul, sepanjang isinya relevan dengan pokok masalah (topik) penelitian. kemudian diinventarisasi dan diklasifikasi sesuai dengan isu hukum yang dibahas dalam penelitian ini. Setelah bahan hukum diinventarisasi dan diklasifikasi, adalah melakukan sistematisasi dan interpretasi terhadap bahan hukum primer dan kemudian dilakukan analisis secara yuridis kualitatif, yaitu analisis hukum yang bertumpu pada penalaran hukum (legal reasoning) dan argumentasi hukum (legal argumentation) secara runtut, dengan ciri-ciri :

a. positivitas, yakni hukum harus memiliki otoritas atau kewenangan; 
b. koherensi, hukum harus dilihat dalam kaitannya dengan aspek-aspek lain sebagai tatanan kehidupan masyarakat; dan

c. keadilan, hukum harus berisi nilai-nilai filosofis yang digunakan untuk mengatur hubungan antar manusia ${ }^{5}$

Analisis hukum tersebut dilakukan untuk menghasilkan proposisi atau konsep sesuai dengan isu hukum yang dibahas dalam penelitian ini. Setelah melakukan analisis (telaah) atas isu hukum yang diajukan berdasarkan bahanbahan hukum yang telah dikumpulkan, langkah selanjutnya, yang dilakukan adalah menarik kesimpulan dalam bentuk argumentasi yang menjawab isu hukum.

Setelah itu, memberikan preskripsi (resep/formula) berdasarkan argumentasi yang telah dibangun kedalam kesimpulan. Langkah ini dilakukan sesuai dengan karakter ilmu hukum sebagai ilmu yang bersifat preskriptif, yang mempelajari tujuan hukum, nilai-nilai keadilan, validitas aturan hukum, konsep-konsep hukum dan norma-norma hukum.

\section{HASIL PENELITIAN}

\section{A. Regulasi Impor Limbah Non-Bahan Berbahaya Dan Beracun Dalam Rangka Perlindungan Dan Pengelolaan Lingkungan}

Bahan Berbahaya dan Beracun adalah zat, energi, dan/atau komponen lain yang karena sifat, konsentrasi, dan/atau jumlahnya, baik secara langsung maupun tidak langsung, dapat mencemarkan dan/atau merusak lingkungan hidup, dan/atau membahayakan lingkungan hidup, kesehatan, serta kelangsungan hidup manusia dan makhluk hidup lain. Adapun limbah Non B3 adalah sisa suatu usaha dan/atau kegiatan berupa sisa, skrap, atau reja yang tidak tcrmasuk dalam klasifikasi atau kategori limbah bahan berbahaya dan beracun.

Dalam Undang-Undang Nomor 32 tahun 2009 tentang Perlindungan dan Pengelolaan Lingkungan Hidup, menyebutkan bahwa setiap orang dilarang:

a. melakukan perbuatan yang mengakibatkan pencemaran dan/atau perusakan lingkungan hidup;

${ }^{5}$ Jazim Hamidi, Makna dan Kedudukan Hukum Naskah Proklamasi 17 Agustus 1945 dalam Sistem Ketatanegaraan Indonesia, Disertasi Program Pascasarjana Universitas Padjajaran, Bandung, 2005, hlm.29. 
b. memasukkan B3 yang dilarang menurut peraturan perundang-undangan ke dalam wilayah Negara Kesatuan Republik Indonesia;

c. memasukkan limbah yang berasal dari luar wilayah Negara Kesatuan Republik Indonesia ke media lingkungan hidup Negara Kesatuan Republik Indonesia;

d. Memasukkan limbah B3 ke dalam wilayah Negara Kesatuan Republik Indonesia;

e. membuang limbah ke media lingkungan hidup;

f. membuang B3 dan limbah B3 ke media lingkungan hidup;

g. melepaskan produk rekayasa genetik ke media lingkungan hidup yang bertentangan dengan peraturan perundang-undangan atau izin lingkungan;

h. melakukan pembukaan lahan dengan cara membakar;

i. menyusun amdal tanpa memiliki sertifikat kompetensi penyusun amdal; dan/atau

j. memberikan informasi palsu, menyesatkan, menghilangkan informasi, merusak informasi, atau memberikan keterangan yang tidak benar.

Huruf d UU 32/2009 menyebutkan : memasukkan limbah B3 ke dalam wilayah Negara Kesatuan Republik Indonesia, memasukkan ini juga termasuk impor ${ }^{6}$ Pasal 106 UU 32/2009 : Setiap orang yang memasukkan limbah B3 ke dalam wilayah Negara Kesatuan Republik Indonesia sebagaimana dimaksud dalam Pasal 69 ayat (1) huruf d, dipidana dengan pidana penjara paling singkat 5 (lima) tahun dan paling lama 15 (lima belas) tahun dan denda paling sedikit Rp5.000.000.000,00 (lima miliar rupiah) dan paling banyak Rp15.000.000.000,00 (lima belas miliar rupiah).

Dalam Pasal 2 Permendag No 84 Tahun 2019 tentang Ketentuan Import Limbah Non B3 sebagai Bahan Baku Industri, sebagaimana yang telah diubah dengan Permendag No. 92 Tahun 2019 tentang Perubahan atas Permendag No. 84 Tahun 2019 tentang Ketentuan Impor Limbah Non B3 sebagai bahan baku Industri, menyebutkan bahwa :

1. Dengan Peraturan Menteri ini, limbah non B3 dapat diimpor

\footnotetext{
${ }^{6}$ Penjelasan Pasal 69 ayat (1) huruf d UU No. 32/2009
} 
2. Limbah Non B3 yang dapat diimpor tercantum dalam Lampiran yang merupakan bagian tidak terpisahkan dari Peraturan Menteri ini.

3. Limbah Non B3 sebagaimana dimaksud pada ayat (2) hanya dapat digunakan untuk bahan baku industri.

Limbah non B3 adalah sisa suatu usaha dan/atau kegiatan berupa sisa, skrap, atau reja yang tidak termasuk dalam klasifikasi atau kategori limbah B3. ${ }^{7}$ Ketentuan impor limbah plastik diatur dalam UU No. 32/2009, UU No. 18/2008, Permendag No. 31/2016. Ketentuan impor limbah plastik ini, antara lain skrap yang diimpor bersih dan tidak terkontaminasi B3 dan limbah B3, harus tersortir dan tidak bercampur dengan sampah dan limbah lainnya, tidak berasal dari kegiatan landfill atau tidak merupakan sampah, harus diolah menjadi produk akhir, dan dokumen impor dilengkapi hasil survei dari KSO (kerja sama operasi).Perubahan terbaru pada Peraturan Menteri Perdagangan No. 84/2019 tentang Ketentuan Impor Limbah Non-Bahan Berbahaya dan Beracun (B3) sebagai Bahan Baku Industri melalui penerbitan Permendag $58 / 2020$.

\section{Mekanisme Impor Limbah Non-Bahan Berbahaya Dan Beracun}

Permohonan untuk mendapatkan pengakuan sebagai Importir Produsen Limbah Non B3 (IPL-Non B3) dari Kemendag sesuai Permendag No. 31/2016, Pasal 6 ayat 1 huruf (k) harus melampirkan rekomendasi KLHK melalui Direktur Jenderal Pengelolaan Sampah, Limbah dan B3. Diatur dalam Surat Perintah Deputi Pengelolaan B3, Limbah B3 dan Sampah, KLHK Nomor: 02/Dep.IV/07/2011 tanggal 22 Juli 2011 tentang Pelaksanaan Penyelesaian Permohonan Izin, Rekomendasi dan Persetujuan Pengelolaan Limbah B3.

7 Menteri Lingkungan Hidup dan Kehutanan Siti Nurbaya menyampaikan lima usulan yang kepada Kementerian Perdagangan melalui rapat kerja dengan Komisi VII DPR RI pada Rabu (15/05/2019) di Gedung DPR, Jakarta. Pertama, pada pos tarif (kode HS) impor limbah non B3 skrap plastik diusulkan tidak ada kode HS lain-lain sehingga skrap plastik yang diimpor tidak tercampur dengan skrap plastik yang tidak dapat di daur ulang di Indonesia. Kedua, tidak ada penambahan importir baru limbah non B3 skrap plastik, Ketiga, pembatasan kuota impor bagi yang sudah beroperasi sampai lima tahun ke depan. Keempat, mengimpor minimal berupa pellet/chips. Kelima, produk hasil daur ulang harus produk jadi bukan berupa kantong plastik. Usulan ini terkait pengelolaan importasi limbah plastik yang buruk. 
Terkait adanya kasus limbah plastik dalam paket impor kertas bekas dari luar negeri yang ditemukan di Surabaya, Dirjen PSLB3 KLHK Rosa Vivien Ratnawati mengatakan bahwa pintu perizinan impor plastik ada di Bea Cukai dan Kemendag. Dalam aturan rekomendasi KLHK sudah jelas kode HS jenis plastik yang masuk ke Indonesia adalah plastik yang sudah di cacah bersih. Untuk rekomendasi ini KLHK memberikan kepada perusahaan yang melakukan impor. Namun jika ditemukan perusahaan yang melakukan ilegal impor, maka akan ditarik rekomendasi dan izinnya. Saat ini proses kasus penyelundupan impor plastik ditangani oleh Kemendag.

Impor Limbah Non B3 sebagai Bahan Baku Industri hanya dapat dilakukan oleh perusahaan pemilik API-P yang telah mendapat PI dari Menteri. Menteri memberikan mandat penerbitan PI kepada Direktur Jenderal. Persetujuan Impor merupakan dokumen pelengkap pabean dalam penyelesaian kepabaeanan di bidang impor. ${ }^{8}$ Limbah Non B3 sebagai Bahan Baku Industri dapat diimpor apabila: tidak berasal dari kegiatan landfill, bukan sampah dan tidak tercampur sampah, tidak terkontaminasi B3 dan Limbah B3, dan homogen.

Kriteria Limbah Non B3 sebagai Bahan Baku Industri yang tidak berasal dari kegiatan landfill dan bukan sampah dan tidak tercampur sampah sebagai berikut: tidak bercampur dengan tanah dan bersih. Impor Limbah Non B3 sebagai Bahan Baku Industri harus berasal dari Eksportir yang terdaftar di negara asalnya, wajib dilakukan pengangkutan secara langsung (direct shipment) sampai di pelabuhan tujuan yang ditetapkan. Jika terbukti tidak dilakukan pengangkutan secara langsung (direct shipment) maka Limbah Non B3 sebagai Bahan Baku Industri wajib dilakukan ekspor kembali oleh importir. Untuk mendapatkan Persetujuan Impor (PI), perusahaan harus mengajukan permohonan secara elektronik kepada Direktur Jenderal melalui laman http://inatrade.kemendag.go.id.dengan mengunggah dokumen asli yang dipersyaratkan, antara lain: rekomendasi kementerian yang menyelenggarakan

${ }^{8}$ Pasal 1 angka 10 Permendag No. 84 Tahun 2019 : Persetujuan Impor Limbah Non 33 Sebagai Bahan Baku Industri yang selanjutnya disingkat PI adalah persetujuan yang digunakan sebagai izin untuk melakukan impor Limbah Non 33 Sebagai Bahan Baku Industri. 
urusan pemerintahan di bidang lingkungan hidup yang diperoleh secara elektronik melalui portal INSW dan rekomendasi kementerian yang menyelenggarakan urusan pemerintahan di bidang perindustrian yang diperoleh secara elektronik melalui portal INSW. Bagi importir yang belum pernah mendapatkan PI, belum terintegrasi dengan portal INSW, rekomendasi asli disampaikan kepada UFTP secara manual. Direktur Jenderal menerbitkan PI dengan menggunakan tanda tangan elektronik (digital signature) paling lama 5 (lima) had kerja terhitung sejak permohonan diterima secara lengkap dan benar.

\section{KESIMPULAN}

1. Regulasi Impor Limbah Non-Bahan Berbahaya Beracun. Undang-Undang Nomor 32 tahun 2009 tentang Perlindungan dan Pengelolaan Lingkungan Hidup, menyebutkan bahwa setiap orang dilarang memasukkan Bahan Berbahaya dan Beracun (B3) yang dilarang menurut peraturan perundang-undangan ke dalam wilayah Negara Kesatuan Republik Indonesia. Dalam Penjelasan Pasal 69 ayat (1) huruf d UU No. 32/2009, memasukkan disini juga termasuk impor. Permendag No. 84 Tahun 2019, Pasal 2 limbah non B3 dapat diimpor. Limbah non B3, yakni sisa suatu usaha dan/atau kegiatan berupa sisa, skrap, atau reja yang tidak termasuk dalam klasifikasi atau kategori limbah B3, dan hanya dapat digunakan untuk bahan baku industri.

2. Mekanisme Impor Limbah Non-Bahan Berbahaya Beracun. Perusahaan harus mengajukan permohonan secara elektronik kepada Dirjen Perdagangan dengan memenuhi persyaratan yang ditentukan, antara lain rekomendasi Kementerian Lingkungan Hidup dan Kementerian Perindustrian. Jika sudah lengkap dan benar, maka Dirjen Perdagangan Persetujuan Impor Limbah Non B3. 


\section{DAFTAR PUSTAKA}

Prajudi Atmosudirdjo, 1978, Hukum Administrasi Negara. Bandung. Alumni

Philipus M. Hadjon (ed), 1995 Pengantar Hukum Administrasi, Yogyakarta. Gajahmada University Press.

Jawahir Tantowi, 2001. Krisis Lingkungan Sebagai Tantangan Global, Analisis Perbandingan Antara Hukum Barat dan Hukum Adat, dalam Hukum dan Lingkungan Hidup di Indonesia, Perpustakaan Nasional, Jakarta

Jimly Asshiddqie, 2010. Konstitusi Ekonomi .Jakarta : Penerbit Buku Kompas

Koesnadi Hardjasoemantri, Hukum Tata Lingkungan, Gadjah Mada University Press, Yogyakarta

WALHI, 1991. Bumi Wahana, Strategi Menuju Kehidupan Berkelanjutan, alih bahasa dari Caring for the Eart, A Strategic for Sustainable Living, IUCN, Jakarta

Sonny Keraf, 2001. Pembangunan Berkelanjutan atau Berkelanjutan Ekologi, artikel dalam Erman Rajagukguk (ed.) Hukum dan Lingkungan Hidup di Indonesia, Perpustakaan Nasional, Jakarta

Takdir Rahmadi, 2015. Hukum Lingkungan di Indonesia, Rajawali Pers. Jakarta

Arne Naess, 1989. Ecology, Community and Lifestyle, Cambridge : Cambridge University Press; The Deep Ecological Movement : Some Philosophical Aspects" Dalam Susan J Amstrong dan Richard G Botzler, Environmental Ethics, Divergence and Convergence, New York : Mc. Graw-Hill, 1993

Jazim Hamidi, 2005. Makna dan Kedudukan Hukum Naskah Proklamasi 17 Agustus 1945 dalam Sistem Ketatanegaraan Indonesia, Disertasi Program Pascasarjana Universitas Padjajaran, Bandung.

Johny Ibrahim, Teori dan Metodelogi Penelitian Hukum Normatif (Surabaya, Bayumedia Johny Ibrahim, Teori dan Metodelogi Penelitian Hukum Normatif (Surabaya, Bayumedia

Undang-Undang Dasar NRI Tahun 1945

Undang-Undang No. 32 Tahun 2009 tentang Perlindungan dan Pengelolaan Lingkungan Hidup

Undang-Undang No. 12 tahun 2011 tentang Pembentukan Peraturan PerundangUndangan

Undang-Undang No. 18 Tahun 2008 tentang Pengelolaan Sampah 
Peraturan Menteri Perdagangan Nomor 31 Tahun 2016 tentang Ketentuan Impor

Peraturan Menteri Perdagangan Nomor 84 Tahun 2019 Tentang

Ketentuan Impor Limbah Non Bahan Berbahaya Dan Beracun Sebagai Bahan Baku Industri

Peraturan Menteri Perdagangan Republik Indonesia Nomor 92 Tahun 2019 Tentang Perubahan Atas Peraturan Menteri Perdagangan Nomor 84 Tahun 2019 Tentang Ketentuan Impor Limbah Non Bahan Berbahaya Dan Beracun Sebagai Bahan Baku Industri

Peraturan Menteri Perdagangan No 58 Tahun 2020 Tentang Perubahan Kedua Atas

Peraturan Menteri Perdagangan Nomor 84 Tahun 2019 Tentang Ketentuan Impor

Limbah Non Bahan Berbahaya Dan Beracun Sebagai Bahan Baku Industri.

https://www.cnbcindonesia.com/news/20190706182210-4-83157/kenapa-indonesiaimpor-sampah 